\title{
The Teaching Reform of Business English Based on Language Economics
}

\author{
ChenBowang \\ Nanchang Institute of Science \& Technology, Nanchang 330108, China
}

Keywords: Language economics, Business English, teaching reform.

\begin{abstract}
In the era of international integration, the trade between the countries is the increasingly close, business English is the important communication tool in foreign-funded enterprises, its importance is more and more obvious, the level of business English skill master directly affects the survival and development of enterprises. But, business English education development is not optimistic in China, the traditional business English teaching mode is increasingly out of touch with the new business environment, it does not meet the needs of present stage economic and social, leading to a shortage of China's business English talents. Therefore, this paper studies business English self value and teaching status quo from the perspective of language economics, to analyze and explicate the our country business English education policies; At the same time, combined with the needs of society and enterprises, this paper puts forward the technical route and measures of the business English teaching reform.
\end{abstract}

\section{Introduction}

After entering WTO, the economic globalization has brought opportunities and challenges to our country, and international trade demands for high level business English talents more and more strongly [1,2]. At the national level, business English can improve the comprehensive competitiveness of the country, and help the country get higher international project value; at the individual level, business English ability determines whether can obtain ideal job. Obviously, business English education needs a large investment in the early stage, and the teaching model makers are easy to ignore the concept of economics [3]. This paper will combine the business English own value and teaching status, to evaluate the economic effectiveness of business English; and then, combined with the needs of society and enterprises, this paper puts forward the reform measures of business English teaching.

\section{Language Economics Theory}

The language economics is a new cross in linguistics and economics, and it also relates to multi discipline frontier science. Through the main use of economic theory paradigm, the economics theory and method are applied to the study of language culture, but also study the relationship between language and the traditional economic variables [4-6]. Since the mid 1960s, when the nature of the language economics was put forward by the pioneer of the information economics Marschak Jacob, the scope of the study of language economics began to become more and more extensive. Language has the value, utility, cost, benefits and other economic characteristics [7-9]. Therefore, theoretically speaking, language economics is the cross and integration of economics and linguistics in theory and method, people can not only use economics theory or method to analyze the language emergence, development and change, but also studies the influence and role of language economic behavior. In recent years, English language has proved its strength in the global market economy, and the language economics has gained some attention and development in China.

\section{Business English Self-value and Teaching Present Situation}

Business English has its own value. Language learning is not only the investment behavior of human resources, but also to gain certain knowledge and skills. At present, the international 
exchanges become more frequent, college students have to learn business English, and we need comprehensive consideration costs and benefits, social open degree, language learning talent and other factors [10]. Expected costs and expected benefits are the unity of opposites, the business English as an economic investment, its cost mainly includes purchase teaching facilities, hire professional teachers, management, service and other aspects; students' learning cost mainly includes tuition, time and energy; expected benefits is personal skills and income increase.

Business English as an applied discipline, social needs are constantly increasing. In recent years, with the increase of foreign trade market share, business English employment advantage is obvious, and the market has been highly recognized [11,12]. Business English is a good extension, English as a tool not only has help or school and employment, but also can make the students with international standards, they can learn more international information and leading technology. The self value of business English is that the professional students can gain the advantage of language and business, and they can engage in the relevant business activities in the world, getting rich economic benefits. The combination of English and business, it can play a greater role in the ability of an English or business, students will more creative through the study or the accumulation.

\section{Business English Teaching Present Situation and Problems.}

(1) Business English teaching situation

People will get benefit from the commercial competition, and the economic benefit is the decisive factor for the development of every company or individual survival. Therefore, the economic benefit is introduced into the teaching mode of business English, and it needs to be used as an important indicator to judge the value of business English [13]. Now it seems that the senior English majors in China is relatively scarce, the proportion of international business will increase with China's international economic status increase, talent shortage is becoming more and more serious, education scholars began to rethink the traditional commercial English education. For foreign trade companies, hiring professional business English talent can bring greater economic benefits to the company than a special English talent, so companies prefer to recruit the compound talents with English and business ability. Based on the above reasons, the business English teaching in China should be that the students can adapt to the international business as the goal, and this kind of advanced composite talents must be comprehensive ability strong, they not only have a good English speaking ability, but also knowledge of business. Therefore, business English teaching is divided into three aspects: the first is the basis of language, namely the teaching of English grammar and vocabulary; the second is knowledge of the business, mainly to teach students the market marketing, enterprise management and international trade knowledge; finally, English practical application, the request of business English major students must have the ability of listening, speaking, reading and writing applications. At present, the opened business English course in Colleges is basically English teaching mode, it is only in accordance with the characteristics of business English teaching setting teaching content from three aspects, and because their own English basis is too large resulting in teaching has a certain fracture phenomenon. For example, because student base has the differences in teaching, leading to the teacher related professional knowledge teaching difficulties, so as to affect the teacher in the teaching effect of business vocabulary and practical application. In addition, due to the heavy task of college students, business English teaching arrangements is limited, resulting in the teacher teaching can not be exhaustive, but also resulting in students must use classroom time as much as possible to learn the knowledge, greatly improving the requirements of students' autonomous learning ability, so this teaching mode is difficult to achieve the ideal economic benefit. Teachers play a crucial role in the process of students' learning business English, we difficultly get good knowledge just by virtue the students' ability, but now teachers in Colleges are due to the lack of practical work experience and feelings, it is difficult to the perfect fusion together teaching between business skills and English language, it indirectly affects the student's comprehension ability, they are difficult to adapt to the post of company arrangement after leading to students participate in the work. At the same time, due to low class in many college business English teaching, the teacher explained the training project is relatively small, teacher can not be timely and effectively get the students feedback in Business 
English application, such training will not only into the a form, leading to the practice teaching is not much effect.

\section{(2) Business English teaching problems}

At present, business English does not obtain the actual effect in most of out colleges, which is composed of three aspects: Firstly, the curriculum is not reasonable, and most of the open business English schools just open economic, management, trade, professional English and other major courses, they has great difference with the market demand; secondly, the qualification of teachers is low, Colleges business English teachers are generally transformed from English majors, they are not too much knowledge of business English and the lack of practical experience in Business English; thirdly, the old teaching model, a lot of business English teaching mode is similar to English majors, they are only their own simple explanations, so students rarely have the opportunity to participate in teaching mode, students are the lack of the innovative consciousness cultivation, directly leading to the low teaching quality.

From the perspective of language economics, the linguistic benefits can be divided into external and internal. External refers to the economic benefits of participating in the work or entering the society, including the actual wage, corporate welfare, social status and so on; Internal is the process of teaching students, namely the pre investment, in addition also includes countries, schools, teachers and students themselves input, these inputs and the proportion of between the late student income and achieve social status determine an important indicator of effective learn business English. Generally speaking, if students' input is greater than the output in learning profession, they can not obtain economic benefits; however, students' input is less than output, we think that students can have certain benefits, and this output is the work results of students, teachers' teaching achievement and so on.

\section{The Exploration of Business English Teaching Reform in the New Perspective}

Through the analysis of business English and teaching situation, it can be seen that he teaching mode of our country business English specialty still has the problem in the angle of language economics, because the professional connection is not comprehensive enough, making teacher's teaching is not in-depth, resulting in a high economic benefit and late students only obtain low benefit, so a lot of teaching resources can not get the corresponding economic benefits. Under the new perspective of business English teaching, this paper puts forward some reform measures and strategies. The technical line of reform measures and strategies is shown in Figure 1. 


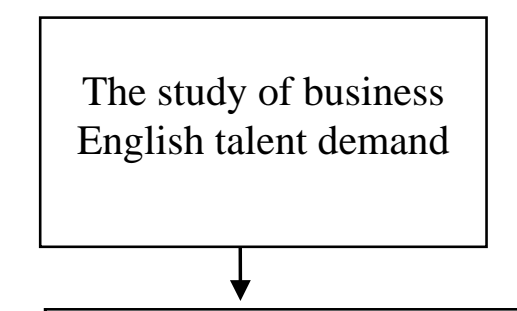

Study on the training mode and curriculum system of business English talent
Study on the value of business English from the perspective of language economics

Study on the correlation between demand analysis, value theory and education development

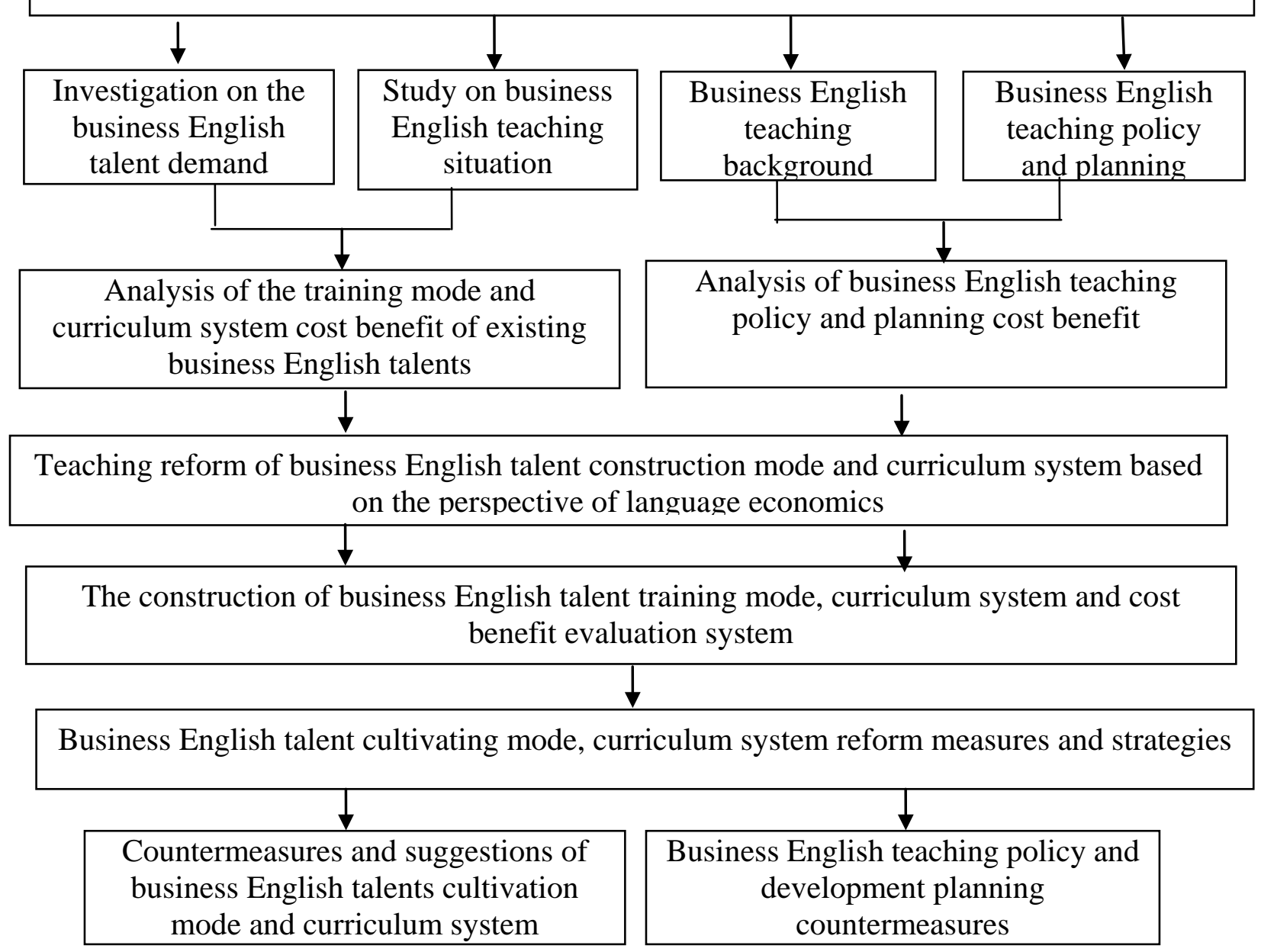

Fig. 1 The technology roadmap of business English reform measures and strategies

As shown in Figure 1, exploring the reform of business English from the perspective of language economics, the first step is to study the domestic and foreign literature as well as to analyze the relevant data; then, analysis of the data information synchronic and diachronic comparison, we study the analysis of business English talents cultivation mode and curriculum system cost benefit, and build the evaluation system of business English talents cultivation mode and curriculum system cost benefit; finally, we put forward the business English training cultivation mode, curriculum system countermeasures, business English teaching policy and development planning countermeasures.

\section{Business English Teaching Reform Goal and Concrete Manifestation}

Business English teaching reform should first determine the reform objectives, improving the quality need of business English teaching from a new perspective should be allocated from the foreign trade knowledge English learning and application ability; ; then according to different students English teaching activities, we encourage students to actively learn knowledge, pay attention to the requirements of the enterprise, and set up the goal of teaching reform according to the enterprise job requirements; more importantly, we should pay attention to the cultivation students' listening, speaking and writing skills, English communication skills, business knowledge etc., at the 
same time, students have strong translation, foreign trade and other practical application ability, so that students can adapt to enterprise requirements after graduation. Whether to meet the needs of the enterprise, it is to determine the specific reflect of education meaning, to cultivate professional talents is an important goal of the current business English teaching reform according to the market demand.

The language economic theory is an important embodiment of business English education reform, and it can achieve the talent training goal of high-quality business English. From the language economics, business English is a kind of capital, we want to master this capital, so we require close understanding language education and understanding language with market efficiency. However, business English teaching mode is easily influenced by traditional English subject in the vast number of colleges and universities, and it does not be reformed according to the employment of students. Therefore, the optimization and reform of business English teaching mode need to start from the optimization course, so it has actual effect in order to achieve the training economic benefits. To be sure, we must reflect the language economics theory in the arrangement of business English teaching content, which can greatly enhance students' learning awareness, so that teachers can obtain the ideal economic effect.

\section{Summary}

Based on the language economic theory, it is the foundation of business English reform. Business English teaching reform should pay attention to in line with the needs of society and enterprise, and then we set up comprehensive teaching mode according to the specific requirements, to enable students to get more comprehensive content. At the same time, we pay attention to have a clear teaching objective, combining the advanced information technology and means with business English teaching mode, which can cultivate more business English talents with high quality and high economic benefit for society and enterprise.

\section{References}

[1] G.H. Liu, W.G. Zhang. Development of language economics in China -- a summary of the first Chinese language and economics forum in 2009. Institutional economics research, 2013(1): 242-248.

[2] Y. Ma, Y. Liu. Research on the local college business English talent school enterprise cooperation culture model from the perspective of language economics. Journal of Heilongjiang Education College, 2013(9): 144-147.

[3] Z.S. Mo. Research on the business English education under the perspective of language economics. Foreign language, 2014(9): 65-72.

[4] L. Tian. Thinking about the ecological niche of business English from the perspective of language economics. Foreign language circle, 2013(4): 26-31.

[5] Q.H. Li, L.R. Ding. The construction of business English practice teaching from the perspective of language economics. Ningbo Vocational and technical college, 2014(6): 58-60.

[6] N. Xu, Y. Liu. Study on the optimization of business English curriculum from the perspective of language economics. Journal of Hunan Commerce University, 2015(2): 119-123.

[7] W. Li. Open interactive network teaching platform and business English teaching reform from the perspective of language economics. Journal of Anhui radio and television university, 2015(2): 60-63.

[8] L. Zhang. Research on the business English practice teaching from the perspective of language economics. Science Journal (late), 2015(11): 83-84.

[9] Y. Yang. Research on business English education from the perspective of language economics. Campus English, 2015(1): 36-38. 
[10] Z.J. Chai. Analysis of business English education research from the perspective of language economics. Business story, 2015(14): 76-77.

[11] Q.S. Kong, A.L. Zou, L.J. Tao. The oriented language economics and its research methods based on market. China business, 2014(11): 178-179.

[12] N.N. Song. A study on the construction of colleges business English courses based on international talents training. Contemporary foreign language study. 2013(6): 45-48.

[13] Q. Yuan, H.Y. Li. An innovative approach of the local college business English talent training mode. Overseas English, 2014(11): 92-93. 